\title{
Tohum Kabuğu Renginin Susam Tohumlarında Bulunan Demir İçeriği Düzeyine Etkisi
}

\section{Cemal KURT ${ }^{\text {D }}$}

Çukurova Üniversitesi Ziraat Fakültesi Tarla Bitkileri Bölümü, Adana

凹: ckurt@cu.edu.tr

\section{ÖZET}

Tarım ürünleri gıda sistemlerinin temel taşını oluşturmaktadır. Son yıllara kadar tarım politikaları, uygulamalar ve araştırmalar birim alandan elde edilen verimin arttırılmasına yönelikti. Birim alandan elde edilecek verimin arttırılması önemli olmakla birlikte, bazı besin maddesi eksikliklerinin azaltılabilmesi için tarımsal ürünlerin bu besin maddeleri yönünden zenginleştirilmesi gerekmektedir. Son yıllarda, tahıllarda mineral maddelerin konsantrasyonlarını arttırmaya yönelik çalışmalar bulunmaktadır ancak yağlı tohumlu bitkilerde, özellikle susamda bu tarz çalışmalar bulunmamaktadır. Islah programlarının oluşturulabilmesi için ebeveyn olarak kullanılacak genotiplerin tanımlanması ve gerekli analizlerin yapılması gerekmektedir. $\mathrm{Bu}$ noktada, diğer bitki türlerinde olduğu gibi susamda da yerel genotipler genetik kaynak olarak büyük önem arz etmektedir. Analizi yaplan, farklı tohum renklerine sahip 24 adet susam örneğinde demir içeriği 27.00 ile $68.89 \mathrm{mg} \mathrm{kg}^{-1}$ arasında değişmektedir. En düşük demir içeriği Diyarbakır-Bismil popülasyonu içerisinden seçilen kahverengi tohum rengine sahip susam örneklerinden elde edilirken, en yüksek değer GaziantepIslahiye popülasyonu içerisinden seçilen beyaz tohum rengine sahip susam örneklerinden elde edilmiştir. Susam örneklerinde tohum rengi siyah>koyu kahverengi $>$ kahverengi şeklinde açıldığında $\mathrm{Fe}$ içeriğinin de azaldığı tespit edilmiştir. Demir içeriği ile tohum kabuğu rengi arasındaki bu ilişki istatistiki olarak da önemli bulunmuş ve farklı gruplar oluşmuştur.
DOI:10.18016/ksudobil.403601

\section{Makale Tarihçesi}

Geliş Tarihi : 09.03.2018

Kabul Tarihi :19.04.2018

Anahtar Kelimeler
Susam,
demir içeriği,
tohum rengi

Araştırma Makalesi

\section{The Effect of Seed Coat Color on The Level of Iron Content in Sesame Seeds}

\begin{abstract}
Agricultural products are the primary source of most nutrients. To date, the primary focus of agricultural research, policy, and practice has been on increasing yields with little attention paid to improving the nutrient output of farming systems. Increasing yields is important but the nutritional quality of crops produced must also be a priority if sustainable progress toward reducing the prevalence of malnutrition is to be realized. In major cereals, a number of genotypes with enhanced concentrations of elements have been developed to improve the nutritional quality of grain for human consumption, but no such major progress has been reported in oilseed crops especially in sesame. Exploring genetic diversity as a source of parents to improve nutritional value of crops is importance in breeding programs. Herein, local genotypes are of great importance as genetic resources in sesame, as in other plant species. The results indicated, the highest iron content was recorded for Gaziantep-Islahiye (white seed color, $68.89 \mathrm{mg} \mathrm{kg}^{-1}$ ) sesame population, while the lowest iron content value was recorded for Diyarbakir-Bismil (brown seed color, $27.00 \mathrm{mg} \mathrm{kg}^{-1}$ ). Iron content was decreased as the seed color turned to black $>$ dark brown $>$ brown. Therefore, the significant correlation were observed between seed color and iron content.
\end{abstract}

\section{Article History}

Received : 09.03.2018

Accepted : 19.04.2018

Keywords
sesame,
iron content,
seed color

Research Article 
To cite : Kurt C 2018. Tohum Kabuğu Renginin Susam Tohumlarında Bulunan Demir İçeriği Düzeyine Etkisi. KSÜ Tarım ve Doğa Derg 21(5): 686-690. DOI:10.18016/ksudobil.403601.

\section{GİRIŞ}

Metabolizmadaki işlevleri açısından 20'den fazla mineral maddeye ihtiyaç duyan insan vücudunda bu minerallerin rolü oldukça önemlidir. Bunlardan en önemlileri Fe, Zn, P, K, Ca, Mg, Cu, Se ve Mn'dır. Bu minerallerden herhangi birinin eksikliği, özellikle çocuklarda öğrenme bozukluklarına, hastalık riskinin ve ölümlerin artmasına ve yüksek sağlık giderlerinin oluşmasına neden olmaktadır. Bu minerallerden eksikliği en yaygın olanı demirdir. Dünya sağlık örgütü raporlarına göre dünya üzerinde 3 milyardan fazla kişide farklı düzeylerde demir eksikliğine dayalı anemi sorunu bulunmaktadır. Demir eksikliği tüm dünyada olduğu gibi ülkemizde de en sık rastlanan besinsel eksiklik olup en sık görüldüğü yaş grupları $6^{-}$ 36 aylık çocuklar ile hamile kadınlardır. Ülkemizde çocuk yaş grubunda yapılan araştırmalarda ise demir eksikliği ve demir eksikliği anemisi oranlarının \%15.2 ile \%62.5 olduğu bildirilmiştir (Dinlen ve ark. 2012). Mineral madde eksikliğinin bu denli yaygın olmasının en büyük sebebi günümüzde insanların mineral içeriği bakımından fakir besinler ile besleniyor olmalarıdır. $\mathrm{Bu}$ durum her geçen gün artış göstermektedir. Yeşil devrimin yapıldığı 1960'lı yıllarda dünyadaki anemi hastası oranı \%30 iken bu rakam 1990'lı yıllarda \%40'lara çıkmıştır (Welch ve Graham, 2002).

Tarım ürünleri gıda sistemlerinin temel taşını oluşturmaktadır. Son yıllara kadar tarım politikaları, uygulamaları ve araştırmaları birim alandan elde edilen verimin arttırılmasına yönelikti. Birim alandan elde edilecek verimin arttırılması önemli olmakla birlikte, besin maddesi eksikliğinin yaygınlı̆̆ının azaltılabilmesi için ürünlerin besin içeriğinin de arttırılması gerekmektedir. Ayrıca mineral madde eksikliğinin giderilmesi için farmakolojik besin takviyeleri almak, günlük yeme alışkanlığındaki besinleri çeşitlendirmek veya gıda ürünlerine mikro madde takviyeleri yapmak gibi yollar da bulunmaktadır. Ancak bu yollar besin eksikliğinin giderilmesinde özelikle gelişmemiş ya da gelişmekte olan ülkelerde pek mümkün olmamaktadır (Pandey ve ark. 2017). Son yıllarda, tahıllarda mineral maddelerin miktarlarını arttırmaya yönelik çalışmalar bulunmaktadır ancak yapılan literatür çalışmalarına göre yağlı tohumlu bitkilerde özellikle susamda bu tarz çalışmaların olmadığı belirlenmiştir. Islah programlarının oluşturulabilmesi için ebeveyn olarak kullanılacak genotiplerin tanımlanması ve gerekli analizlerin yapılması gerekmektedir. $\mathrm{Bu}$ noktada, diğer bitki türlerinde olduğu gibi susamda da yerel genotipler genetik kaynak olarak büyük önem arz etmektedir. Susam tohumları yağ (\%50), protein (\%24), vitaminler, mineraller ve antioksidanlar içermektedir (Kurt, 2018). Susam tarımı ülkemizde
M.Ö. 2000 yılından beri yapılmaktadır ve önemli bir genetik kaynağa sahiptir (Ümmetoğlu ve ark. 2015). Türkiye'de susam ekiliş alanı 2017 yılında 280,309 da, üretim ise 18,410 ton olarak gerçekleşmiştir (TÜİK, 2017). Ülkemizde 2013 yılında yapılmış olan susam ithalatı ise 106,845 ton susam tohumu için 182,137,000 dolardır (FAO, 2013). Ülkemizde üretilen susamlar genellikle popülasyon özelliğinde, yani farklı özellikteki susam tohumlarını karışık bir şekilde ihtiva etmektedir. Susam çok önemli bir yă̆ bitkisi olmasına rağmen, ülkemizde üretilen ve ithal edilen susamin tamamina yakını gida olarak; tahin yapımında, firıncılık ve pastanecilik sektörlerinde kullanılmaktadır. Bu nedenle, tüketilen susamların besleyicilik özelliklerinin saptanması büyük önem arz etmektedir.

Dünya üzerinde yayılış gösteren çok sayıdaki susam çeşitleri; beyazdan, siyaha kadar değişen, farklı tohum renklerine sahiptir (Ashri, 1989; Weiss, 2000). Susamda tohum kabuğu rengi ile içerik maddeleri arasında yakın ilişkiler bulunmaktadır. Koyu renkli tohumlar, açık renkli tohumlara göre daha yüksek protein, daha düşük yağ içermektedir (Baydar ve ark. 1999). Yine koyu renklilikten, açık renkliliğe doğru gidildikçe, düzenli olarak yağda linoleik asit oranı artarken, oleik asit oranı azalmaktadır (Baydar ve ark. 1999). Ancak, tohum renginin, tohumun demir içeriği üzerine etkisinin saptandığı bir çalışma bulunmamaktadır. Bu çalışmanın amacı; ülkemizde ve Suriye'de yetişen bazı susam popülasyonlarını ihtiva ettikleri renklere göre ayırıp, tohum kabuğu renginin demir içeriğine olan etkisini saptamaktır.

\section{MATERYAL ve YÖNTEM}

\section{Materyal}

Çalışmada materyal olarak Türkiye'nin farklı illerinden 9 ve Suriye'den 2 adet susam popülasyonu kullanılmıştır. Susam popülasyonları Çukurova Üniversitesi, Ziraat Fakültesi, Tarla Bitkileri Bölümü, Araştırma ve Deneme Alanında 2014 yılı ikinci ürün koşullarında yetiştirilmiştir. Materyal listesi ve içerdikleri tohum kabuğu renkleri Çizelge 1'de verilmiştir.

\section{Fe içeriğinin belirlenmesi}

Bitkiler hasat edildikten sonra çalışmada kullanılan susam popülasyonları, içerdikleri renklere göre ayrılmıştır (Şekil 1). Renklerine göre ayrılmış olan bu örnekler parçalanması için yaklaşık $0.5 \mathrm{~g}$ numune yakma ünitesi kabına tartılarak üzerine $5 \mathrm{~mL} \% 65$ 'lik nitrik asit ve $2 \mathrm{~mL} \% 35$ 'lik hidrojen peroksit ilave edilmiştir. Parçalama işleminin tamamlanmasından sonra örnek çözelti hacmi ultra saf su ile $20 \mathrm{~mL}$ ye tamamlanmıştır. 

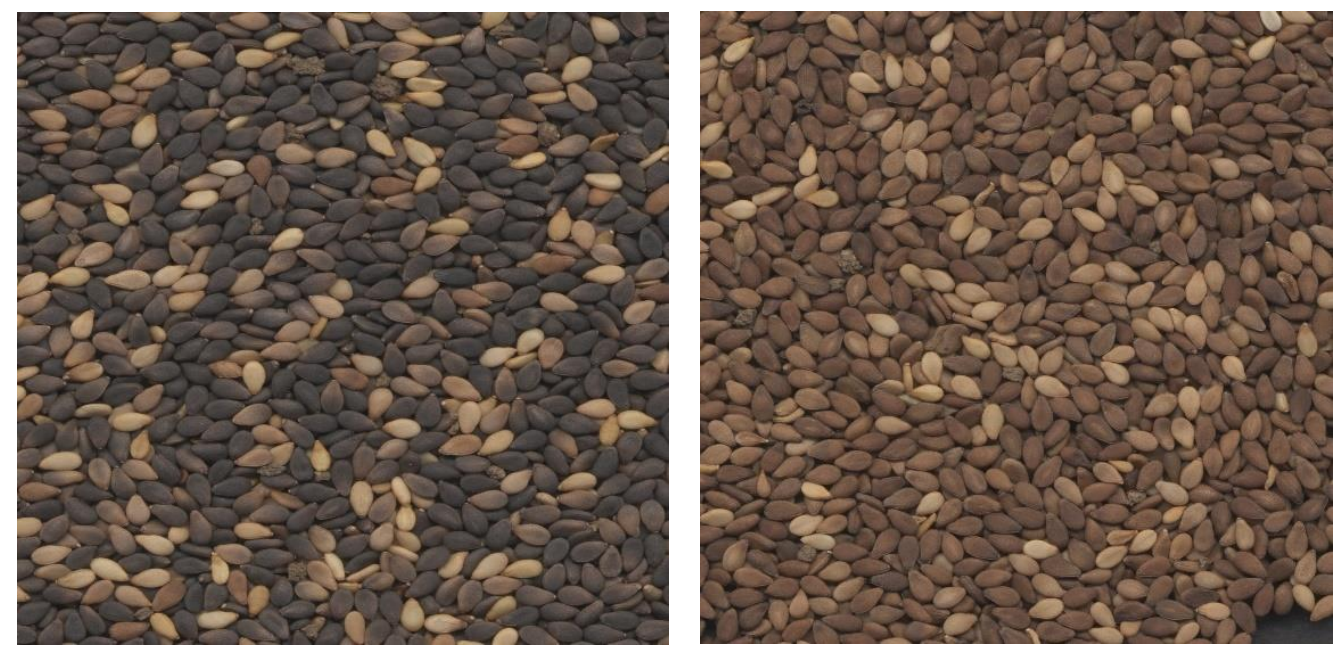

Şekil 1. Farklı tohum kabuğu rengine sahip susam popülasyonları

Çizelge 1. Çalışmada kullanılan susam popülasyonları ve bunların içerdiği tohum renkleri

\begin{tabular}{|l|l|l|l|}
\hline Popülasyon Adı & \multicolumn{4}{l|}{ İçerdiği Tohum Renkleri } \\
\hline Diyarbakır-Bismil & Siyah & Koyu kahverengi & Kahverengi \\
\hline Suriye-1 & Kahverengi & Koyu Kahverengi & \\
\hline Diyarbakır-Ergani & Siyah & Koyu Kahverengi & \\
\hline Antalya-Finike & Kahverengi & Koyu Kahverengi & \\
\hline Gaziantep-Islahiye & Beyaz & Kahverengi & \\
\hline Siirt & Siyah & Koyu kahverengi & Kahverengi \\
\hline Suriye-2 & Kahverengi & Koyu Kahverengi & \\
\hline Diyarbakır-Çınar & Kahverengi & Koyu Kahverengi & \\
\hline Aydın-Yenipazar & Kahverengi & Koyu Kahverengi & \\
\hline Osmaniye & Kahverengi & Koyu Kahverengi & \\
\hline Iğdır & Siyah & Kahverengi & \\
\hline
\end{tabular}

Susam tohumlarinda ICP-OES (ICP-OES; Vista-Pro Axial; Varian Pty Ltd., Australia) cihazı kullanılarak Demir miktarı tayin edilmiştir. Analizler 3 tekerrürlü olarak yapılmıştır.

\section{İstatistik analizi}

Elde edilen sonuçlar R paket programı kullanılarak ANOVA testine tabi tutulmuş ve popülasyon içerisindeki oluşan farklılıklar ve gruplar Tukey (\%5) testine göre belirlenmiştir.

\section{BULGULAR ve TARTIŞMA}

Susamda tohum kabuğu rengi ticari öneme sahip bir özelliktir ve ülkelere göre farklılık göstermektedir. Japonya'da tüketiciler siyah renkli çeşitleri tercih ederken, Sudan ve Türkiye'deki tüketiciler ise beyaz renkli susamı tercih etmektedir (Pandey ve ark., 2013; Kurt, 2018). Analizi yapılan, farklı tohum renklerine sahip 24 adet susam örneğinde demir içeriği 27.00 ile $68.89 \mathrm{mg} \mathrm{kg}^{-1}$ arasında değişmektedir. En düşük demir içeriği Diyarbakır-Bismil popülasyonu içerisinden seçilen kahverengi tohum rengine sahip susam örneklerinden, en yüksek değer Gaziantep-Islahiye popülasyonu içerisinden seçilen beyaz tohum rengine sahip susam örneklerinden elde edilmiştir. Çizelge 2'de görüldüğü üzere, susam örneklerinde tohum rengi siyah $>$ koyu kahverengi $>$ kahverengi şeklinde açıldığında demir içeriğinin de azaldığ edilmiştir. Demir içeriği ile tohum kabuğu rengi arasındaki bu ilişki istatistiki olarak da önemli bulunmuş ve farkl gruplar oluşmuştur. Ancak beyaz susam rengi ile demir içeriği arasında bir ilişki saptanamamıştır. Siyah renge sahip popülasyonlar içerisinde en düşük değer (41.55 mg kg-1) DiyarbakırErgani popülasyonuna ait iken en yüksek değer (58.29 mg kg-1) Iğdır popülasyonundan elde edilmiştir. Koyu kahverengi tohum rengine sahip popülasyonlarda ise en yüksek değer (67.42 $\left.\mathrm{mg} \quad \mathrm{kg}^{-1}\right) \quad$ Osmaniye popülasyonuna ait iken, en düşük değer (30.42 mg kg-1) Diyarbakır-Ergani popülasyonuna ait olduğu belirlenmiştir (Çizelge 2). 
Çizelge 2. Çalışmada kullanılan susam popülasyonları ve tohum renklerine göre demir miktarları

\begin{tabular}{|c|c|c|c|c|c|}
\hline \multirow[t]{2}{*}{ Popülasyon Adı } & \multicolumn{5}{|c|}{ Demir miktarı $\left(\mathrm{mg} \mathrm{kg}^{-1}\right)$} \\
\hline & Siyah & Koyu Kahverengi & Kahverengi & Beyaz & Sig.. \\
\hline Diyarbakır-Bismil & $50.31^{a}$ & $38.76^{\mathrm{ab}}$ & $27.00^{\mathrm{b}}$ & & $0.0116^{*}$ \\
\hline Suriye-1 & & $53.30^{\mathrm{a}}$ & $38.59^{b}$ & & $0.0476^{*}$ \\
\hline Diyarbakır-Ergani & $41.55^{\mathrm{a}}$ & $30.42^{\mathrm{b}}$ & & & $0.00848^{* *}$ \\
\hline Antalya-Finike & & $47.31^{\mathrm{a}}$ & $44.66^{\mathrm{b}}$ & & $0.0268^{*}$ \\
\hline Gaziantep-Islahiye & & & 57.22 & 68.89 & Ö.D \\
\hline Siirt & $58.29^{\mathrm{a}}$ & $52.21^{\mathrm{ab}}$ & $42.94^{\mathrm{b}}$ & & $0.0336^{*}$ \\
\hline Suriye-2 & & $53.70^{\mathrm{a}}$ & $46.46^{\mathrm{b}}$ & & $0.00006^{* * *}$ \\
\hline Diyarbakır-Çınar & & $49.57^{\mathrm{a}}$ & $38.67^{\mathrm{b}}$ & & $0.0151^{*}$ \\
\hline Aydın-Yenipazar & & $53.56^{\mathrm{a}}$ & $49.50^{b}$ & & $0.0282^{*}$ \\
\hline Osmaniye & & $67.42^{\mathrm{a}}$ & $56.47^{\mathrm{b}}$ & & $0.00959^{* *}$ \\
\hline Iğdır & $57.41^{\mathrm{a}}$ & & $34.07^{\mathrm{b}}$ & & $0.000203^{* * *}$ \\
\hline En Yüksek & 58.29 & 67.42 & 57.22 & & \\
\hline En Düşük & 41.55 & 30.42 & 27.00 & 68.89 & \\
\hline Ortalama & 51.89 & 49.58 & 43.56 & 68.89 & \\
\hline
\end{tabular}

*:0.01; **:0.001; ***:0.0001; Ö.D: Önemli Değil

$\mathrm{Bu}$ sonuçlardan da görüleceği üzere sadece popülasyonların demir içerikleri belirlenmiş olsaydı arada oluşan bu fark tohum renginden değil de popülasyonların genetik potansiyellerinden kaynaklanmış olabilirdi.

Pandey ve ark., (2017) farklı bölgelere ait 60 adet susam genotipinde yapılmış olan çalışmada demir miktarının 35.2 ile $231.5 \mathrm{mg} \mathrm{kg}^{-1}$ arasında değiştiğini tespit etmişler. Ayrıca yaptıkları çalışmada, siyah renkli susam tohumlarinın ortalama demir miktarı $134.12 \mathrm{mg}$ $\mathrm{kg}^{-1}$ iken kahverengi susam tohumlarmm ortalama demir miktarının $97.27 \mathrm{mg} \mathrm{kg}^{-1}$ olduğunu ve tohum kabuğu renginin demir içeriği üzerine etkisinin olduğunu bildirmişlerdir.

Kanu (2011), siyah ve beyaz renkli susamlarda yapmış olan bir çalışmada siyah renkli susamların $\left(121 \mu \mathrm{g} \mathrm{g} \mathrm{g}^{-1}\right)$ beyaz renkli susamlardan $\left(111 \mu \mathrm{g} \mathrm{g}^{-1}\right)$ daha yüksek demir içeriğine sahip olduğunu bildirilmiştir. Ancak yapılmış olan bu çalışmada kullanılan materyal sayısı sadece 2 adet olduğu için elde edilen sonuçlar tartışmaya açıktır.

Bhardwaj ve ark., (2014) çeşitlerin, ekim tarihlerinin ve ekim sıklıklarının verim ve mineral madde içeriğine etkilerini tespit etmek için yapılan bir çalışmada, 5 adet susam çeşidi kullanılmış ve demir içeriğinin 107 ile 114 $\mathrm{mg} \mathrm{kg}{ }^{-1}$ arasında değiştiğini bildirilmiştir. Denemeye aldıkları çeşitler arasında demir içeriği yönünden bir farklılık olmadığını da tespit etmişlerdir.

Tohum kabuğu rengi ile besin değeri arasındaki ilişki hakkında bilgiler oldukça sınırlıdır. Bu nedenle, bu konuda farklı bitkiler ile yapılan çalışmalar da önem arz etmektedir. Silva ve ark., (2012) 100 adet barbunya ile yapılan bir çalışmada, siyah renge sahip olan genotiplerin en yüksek demir içeriğine sahip olduğu bildirmiştir. Moraghan ve ark., (2002) tarafından fasulyede yapılmış bir başka çalışmada ise siyah renkli genotiplerin daha yüksek demir içeriğine sahip olduğu ve bunun da nedeninin, siyah renkli tohumların içerdikleri tanninden kaynaklandığı bildirilmiştir.

Susamda ve farklı bitkilerde yapılan çalışmalarda olduğu gibi bu çalışmada da tohum kabuğu rengi ile demir içeriği arasında bir ilişkinin olduğu görülmektedir.

\section{SONUÇ}

Susamda tohum rengi tüketiciler için önemli bir tercih sebebidir. Son yıllarda toplumda sağllklı yaşam algısının artmasından dolayı daha sağlıklı gıda talebi oluşmuştur. $\mathrm{Bu}$ nedenle farklı tohum rengine sahip susam çeşit ve popülasyonlarının besin içeriklerinin belirlenmesi, tüketicinin ürün seçimine yardımcı olacaktır.

Yapılan analizler sonucunda tohum kabuğu rengi siyah $>$ koyu kahverengi $>$ kahverengi şeklinde açıldığında demir içeriğinin de renk açıldıkça azaldığg tespit edilmiştir.

\section{KAYNAKLAR}

Ashri A 1989. Sesame. Oil Crops of the World. Robbelen, G.; Downey, R.K.; and A. Ashri (eds.). McGraw-Hill Publishing Company: New York. pp. 375-387

Baydar H, Marquard R, Turgut I 1999. Pure line selection for improved yield, oil content and different fatty acid composition of sesame, Sesamum indicum. Plant Breed. 118(5): 462-464.

Bhardwaj HL, Hamama AA, Kraemer ME, Langham DR 2014. Cultivars, planting dates, and row spacing effects on sesame seed yield and mineral composition. Journal of Agricultural Science; 6(9): 17.

Dinlen N, Çayır A, Fettah A, Şaylı TR 2012. Demir eksikliği anemisi tedavisinde iki ve üç değerlikli 
demirin etkinliği ve multivitamin desteğinin tedaviler üzerine etkisi. Çocuk Dergisi, 12 (2): 72-77

FAO 2013. http://www.fao.org/faostat/en/\#data/TP

Kanu PJ 2011. Biochemical analysis of black and white sesame seeds from China. American Journal of Biochemistry and Molecular Biology, 1 (2): 145-157

Kurt C 2018. Variation in oil content and fatty acid composition of sesame accessions from different origins. Grasas Y Aceites 69 (1) January-March, e241

Moraghan JT, Padilla J, Etchevers JD, Grafton K, Acosta-Gallegos JA 2002. Iron accumulation in seed of common bean. Plant and Soil 246: 175-183

Pandey SK, Das A, Dasgupta T 2013. Genetics of seed coat colour in sesame (Sesamum indicum L.). Afr J Biotechnol 12:6061-6066

Pandey SK, Majumder E, Dasgupta T, 2017. Genotypic Variation of Microelements Concentration in
Sesame (Sesamum indicum L.) Mini Core Collection. Agric Res. 6(2) : 114-121.

Silva CA, de Fátima Barbosa Abreu, Ramalho MAB, Maia LGS 2012. Chemical composition as related to seed color of common bean. Crop Breeding and Applied Biotechnology 12: 132-137.

TÜIK, 2017. $\quad$ https://biruni.tuik.gov.tr/medas l?kn=92\&locale=tr

Ümmetoğlu M, Taşkın T, Tan AŞ 2015. Manisa il ve ilçelerinde yetiştirilen susam çeşitlerinin dağılımı ve mevcut durumunun araştırılması. Anadolu Ege Tarımsal Araştırma Enstitüsü Dergisi, 25 (2) :37- 58 Weiss EA, 2000. Oilseed crops. 2nd ed. Oxford: Blackwell Science. Oxford, U.K.

Welch RM, Graham RD, 2002. Breeding crops for enhanced micronutrient content. Plant and Soil 245:205-214 